http://www.pakjas.com.pk

\title{
POLYMORPHISMS IN GROWTH HORMONE (GH) AND INSULIN-LIKE GROWTH FACTOR-1 (IGF-1) GENE AND THEIR ASSOCIATION WITH GROWTH TRAITS IN BEETAL GOAT
}

\author{
Mehwish Shareef ${ }^{1, *}$, Atia Basheer ${ }^{1}$, Imran Zahoor ${ }^{1}$ and Aftab Ahmad Anjum ${ }^{2}$ \\ ${ }^{1}$ Department of Livestock Production; ${ }^{2}$ Department of Microbiology, University of Veterinary and Animal Sciences, \\ Lahore, Pakistan \\ *Corresponding author's e-mail: meshi_786@ hotmail.com
}

\begin{abstract}
Beetal is one of the most famous goat breed of Pakistan which is also present in parts of Indian Punjab. It is popular for its larger body size, higher body weight, and good ability to produce milk. In current study, polymorphism in Growth Hormone (GH) and Insulin-like Growth Factor-1 (IGF-1) genes and their association with growth-related traits were studied in Beetal goat. On the basis of previously reported mutations, a set of 7 primer pairs were designed to screen PCR-RFLP based polymorphisms in 60 random selected Beetal goats varying in body weight. The IGF-1 gene was found polymorphic and following three genotypes ( $\mathrm{AA}, \mathrm{AB}$, and $\mathrm{BB}$ ) were detected in tested animals with the frequency of mutant (B) and wild-type (A) alleles as 0.35 and 0.65 respectively. Homozygous carrier genotype $(\mathrm{BB})$ was significantly associated $(\mathrm{P}<0.05)$ with higher body weight $(47.13 \pm 0.78 \mathrm{~kg})$ followed by heterozygous carrier (BB) and wild-type (AA) genotype associated with $40.45 \pm 0.31 \mathrm{~kg}$ and $38.18 \pm 0.37 \mathrm{~kg}$ body weight respectively. Additionally, maximum wither height and body length were observed in $\mathrm{BB}(32.25 \pm 0.33,31.93 \pm 0.27$ inches) genotype followed by $\mathrm{AB}(31.93 \pm 0.27,31.16 \pm 0.35)$ and $\mathrm{AA}(31.62 \pm 0.68$, $30.87 \pm 0.86)$ genotype. Moreover, maximum heart girth was also observed in BB (33.65 \pm 0.11$)$ genotype. All known point mutations of GH gene were found monomorphic in the tested animals. Upon sequencing of GH gene, one non-synonymous SNP was identified in exon 2 at $825 \mathrm{bp}$ position that caused a change of amino acid Threonine into Alanine. And likewise one insertion variant in intron 4 was observed at position $1546 \mathrm{bp}$ in this gene. The results showed that homozygous carrier animals, having BB genotype in IGF-1 gene, were having the highest values for growth traits suggesting the additive effects of mutant (B) allele on growth traits in this breed. On the basis of our results it is suggested that the identified markers can be used in marker-assisted-selection (MAS) in Beetal goat.
\end{abstract}

Keywords: GH gene, IGF-1 gene, PCR-RFLP, growth traits, Beetal goat, DNA sequencing

\section{INTRODUCTION}

Beetal is the most well-known and famous goat breed of Pakistan which is also present in parts of Indian Punjab (Khan et al., 2008). It is considered a noteworthy goat breed due to its high body weight, large body size, good milking strength, and reasonable rate of fecundity (Khan and Ashfaq, 2012). Its most significant characteristic is better adaptability in a range of environmental conditions which makes it a highly preferred breed for intensive goat farming in tropical and subtropical regions of the world (Khan and Ashfaq, 2012). Goat meat is a preferred type of mutton in a number of Asian and African countries compared with other types of meat. Moreover, during outbreaks of some avian diseases like bird flu most of the poultry meat consumers switch to mutton which further increases its demand.

In small ruminant production, growth traits are always of foremost concern of breeders due to ever growing demand for mutton and its high economic value (Zhang et al., 2008c; Hua et al., 2009). Growth hormone (GH) is of high biological significance because of its role in affecting different traits in livestock species such as growth rate, body structure, health, milk yield, reproduction (Scaramuzzi et al., 1999; Malveiro et al., 2001) and metabolism (Jiang and Lucy 2001; Supakorn et al., 2007; An et al., 2011). The growth hormone (GH) is synthesized as well as released by the somatotroph cells of anterior pituitary and its secretion is strongly controlled and activated by growth hormone releasing hormone (GHRH) (Dettori et al., 2015).

GH gene have been the main focus of genetic studies on small ruminant and a number of variations like the identification of haplotypes in exon 4 and 5 of GH gene in Black Bengal goat (Gupta et al., 2009), PCR-RFLP based polymorphism in Sirohi and Barbari breeds (Singh et al. 2015), 5 point mutations in in Osmanabadi and Sangamneri goat breeds (Wickramaratne et al., 2011), and some variants associated with growth in Boer goat (Hua et al., 2009; Ishida et al., 2010) have been reported. Likewise, Ishida et al. (2010) reported genetic polymorphism of bovine growth hormone gene associated with calf weight in Japanese Black cattle. Additionally, some polymorphisms in GH gene had also been found associated with milk yield in goat (Malveiro et al., 
2001; Lan et al., 2007) and milk composition in sheep (Dettori et al., 2015).

GH secretion leads to switching on of IGF-1 gene and results in its enhanced expression in the liver. IGF-1 is single-chain polypeptide fundamentally homologous with insulin which plays a vital role in a many biological processes such as embryogenesis, growth and lactation, increase in glucose uptake, stimulation of myogenesis, inhibition of apoptosis and reproduction, (Bai et al., 2013). Some QTLs for growth and body confirmation traits have been found in goat on chromosome 5 (Tu et al., 2016) encompassing IGF-1 gene (De la Rosa Reyna et al., 2010). Moreover, polymorphism in IGF-1 gene and its flanking regions had been found associated with birth weight, growth rate, live weight, and carcass weight in different breeds of sheep and goat like in Zel sheep (Kazemi et al., 2011), in Kurdish goat (Rasouli et al., 2017), in Nanjiang Huang goats (Zhang et al., 2008c), in Egyptian sheep and goat breeds (Othman et al., 2016), in Indian goat breeds (Sharma et al., 2014) and in Russian Merino sheep (Trukhachev et al., 2016).

However, the numbers of studies on the exploration of candidate genes for growth traits in Beetal goat are very few which is the major hurdle in the implementation of markerassisted selection in this breed. In order to bridge the growing gap between demand and supply of goat meat there is need to find out the genetic variants affecting growth in this breed in order to enhance its genetic potential for growth-related traits.

\section{MATERIALS AND METHODS}

Ethical statement: Permission (number DR/152) for the collection of blood samples was obtained from the Ethical Review Committee for animal research of University of Veterinary and Animal Sciences, Lahore, Pakistan.

Experimental Animals/blood sampling and DNA extraction: In total 60 healthy adult Beetal goats were selected on the basis of variation in their body weight. Animals were divided into two body weight categories i.e. 30 heavy and 30 low weight animals. Phenotypic data for different traits including body weight, wither height, body length, and heart girth were recorded. Blood samples with a volume of $5 \mathrm{ml}$ from each goat were collected aseptically from jugular vein into $50 \mathrm{ml}$ falcon tubes containing $160 \mu \mathrm{l}(0.5 \mathrm{M})$ EDTA. DNA extraction was performed by using inorganic method described by (Sambrook and Russell, 2001).

DNA amplification by PCR: Polymerase chain reaction (PCR) was carried out in a final reaction volume of $25 \mu \mathrm{l}$ in C1000 Touch ${ }^{\mathrm{TM}}$ Thermal Cycler (BIO-RAD, USA). A set of 7 primers pairs for the amplification of different regions of $\mathrm{GH}$ and IGF1 gene were taken from previously published literature (Table 1). The reaction mixture consisted of $200 \mu \mathrm{M}$ dNTPs, $1.5 \mathrm{mM} \mathrm{MgCl} 2,2.5 \mathrm{mM} 10 \mathrm{x}$ buffer, 30ng each of forward and reverse primer and 1 Unit Taq DNA polymerase. The PCR reaction cycle was accomplished by denaturation for $1 \mathrm{~min}$ at $94^{\circ} \mathrm{C} ; 30$ cycles of denaturation at $94^{\circ} \mathrm{C}$ for $45 \mathrm{~s}$, annealing $56-63^{\circ} \mathrm{C}$, and extension step at $72^{\circ} \mathrm{C}$ for $45 \mathrm{~s}$ with a final extension at $72^{\circ} \mathrm{C}$ for $5 \mathrm{~min}$. The PCR products were visualized in Gel Doc ${ }^{\mathrm{TM}} \mathrm{EZ}$ imager (BIO-RAD, USA) following electrophoresis through $2 \%$ agarose gel.

PCR-RFLP analysis: Amplified PCR products of all the primer sets (Table 1) were digested with restriction enzyme HaeIII at $37^{\circ} \mathrm{C}$ for 12 hours. After digestion, the samples were stored at $4^{\circ} \mathrm{C}$. The digested product was visualized in Gel Doc $^{\mathrm{TM}}$ EZ imager (BIO-RAD, USA) following electrophoresis through $2 \%$ agarose gel. The gel images were recorded in a gel documentation system.

Sequencing and Analysis: The amplified regions were sequenced using an ABI3130 automated DNA Sequencer (Applied Biosystems, USA). Multiple sequence alignments were performed with MEGA 7 (Sudhir et al. 2016) software using CLUSTALW algorithm (Thompson et al., 1994) to identify polymorphisms. The coding DNA sequences of

Table 1. List of Primers along with their amplified region, amplicon size, and references

\begin{tabular}{|c|c|c|c|c|}
\hline Gene & Primer Sequence & Amplified Region & Amplicon Size (bp) & Reference \\
\hline \multirow[t]{2}{*}{ GH1 } & F:CTCTGCCTGCCCTGGACT & Exon 2 and exon 3 & 422 & (Hua et al. 2009) \\
\hline & R:GGAGAAGCAGAAGGCAACC & & & \\
\hline \multirow[t]{2}{*}{ GH2 } & F:TCAGCAGAGTCTTCACCAAC & Exon 4 & 116 & (Hua et al. 2009) \\
\hline & R:CAACAACGCCATCCT CAC & & & \\
\hline \multirow[t]{2}{*}{ GH3 } & F: CGACGCCATAGACAGCAG & Partial exon 1 & 419 & (Supakorn et al. \\
\hline & R: CATTTATGCAAGGACCACTGG & & & 2007) \\
\hline \multirow[t]{2}{*}{ GH4 } & F:TAGGGGAGGGTGGAAAATGGA & Exon 5 & 404 & (Silveira et al. \\
\hline & R:GACACCTACTCAGACAATGCG & & & 2008) \\
\hline \multirow[t]{2}{*}{ GH5 } & F: GCCAGTGGTCCTTGCATAAA & Exon 1 and partial exon 2 & 500 & (Supakorn et al. \\
\hline & R: AGTCCAGGGCAGGCAGAG & & & 2007) \\
\hline GH6 & F: CCATCCAGAACACCCAGGT & Partial exon 3 and partial & 417 & (Supakorn et al. \\
\hline \multirow{2}{*}{ IGF-1 } & $\begin{array}{l}\text { R: CCAAGCTGTTGGTGAAGACTC } \\
\text { F:CACAGCGTATTATCCCAC }\end{array}$ & $\begin{array}{l}\text { exon } 4 \\
\text { Exon } 4 \text { and partial intron } 4\end{array}$ & 363 & $\begin{array}{l}\text { 2007) } \\
\text { (Liu et al. 2010) }\end{array}$ \\
\hline & R:GACACTATGAGCCAGAAG & & & \\
\hline
\end{tabular}


different exon regions were translated to amino acid sequences using Chromaspro software.

Statistical Analysis: The General Linear Model procedure of Genstat, version 18 (Payne et al., 2011) was used to test the effects of genotypes on the body weight, body length, body height, and heart girth. The linear model used to analyzed the data is as follow

$\mathrm{Y}_{\mathrm{ijkl}}=\mu+\mathrm{S}_{\mathrm{i}}+\mathrm{P}_{\mathrm{j}}+\mathrm{W}_{\mathrm{k}}+\mathrm{G}_{\mathrm{l}}+\mathrm{e}_{\mathrm{ijk} \mathrm{l}}$

Where, $\mu=$ Population mean

$\mathrm{S}=$ Season of Birth, $\mathrm{i}=[1$, and 2]

$\mathrm{P}=$ Parity, $\mathrm{j}=[1,2$, and 3$]$

$\mathrm{W}=$ Year of Birth, $\mathrm{k}=[1,2,3$, and 4]

$\mathrm{G}=$ Genotype, $\mathrm{l}=[1,2$, and 3$]$

$\mathrm{e}=$ Random Residual Error

\section{RESULTS}

Present study was conducted in order to identify polymorphism in $\mathrm{GH}$ and IGF-1 candidate genes and to determine their association with growth traits in Beetal goat breed.

Polymerase Chain Reaction (PCR) of Growth Hormone Gene: The five exons of Growth hormone (GH1) gene were amplified by PCR using exon specific primer sets (Table 1). The amplified products were run on $1.2 \%$ (W/V) agarose gel electrophoresis along with DNA ladder that was used as size standard.
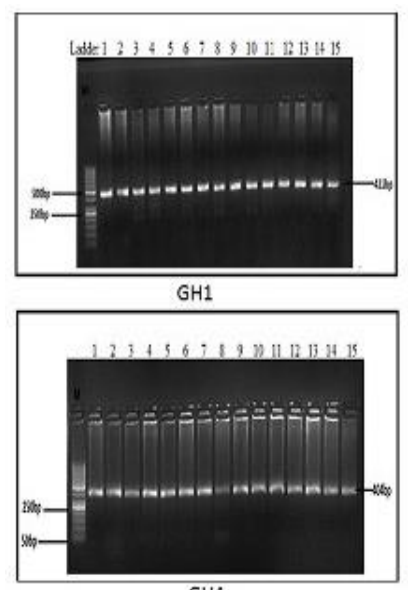

GH4
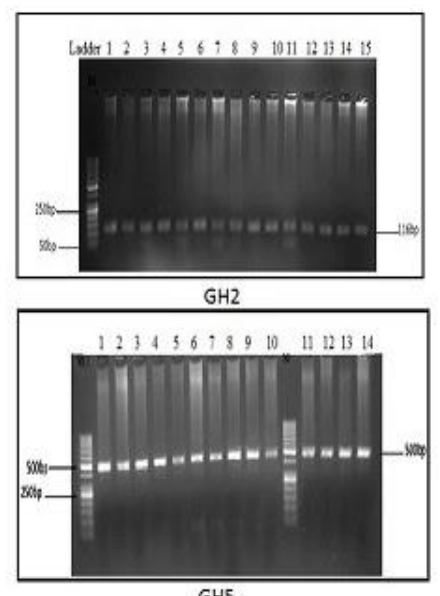

GHS

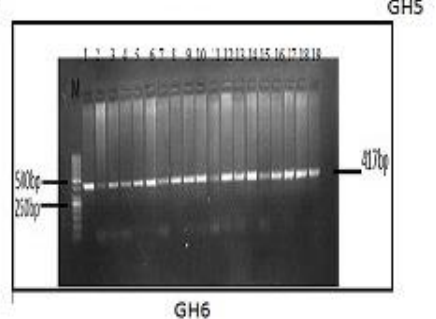

Figure 1. Amplified PCR products GH1 was $422 \mathrm{bp}$, GH2 was $116 \mathrm{bp}$, GH3 could not be amplified, GH4 was $404 \mathrm{bp}$, GH5 was $500 \mathrm{bp}$ and GH6 was $417 \mathrm{bp}$.
The sizes of target amplified products for GH1, GH2, GH4, GH5, and GH6 were 422 base pair (bp), 116bp, 404bp, 500bp, and $417 \mathrm{bp}$, respectively, as shown in Figure 1. However, the PCR conditions for the GH3 primer set could not be optimized.

PCR-Restriction Fragment Length Analysis of Growth hormone (GH) gene: Several techniques are available to identify the single nucleotide polymorphism (SNP) in target sequence. However, one of the most common method is the PCR-RFLP analysis to detect the genetic polymorphism in target gene. It is a powerful method for identifying nucleotide sequence variation in amplified DNA and can detect single base variations in enzymatic restriction sites.

In this study, we used the PCR-RFLP technique for the identification of SNP in five exons of growth hormone $(\mathrm{GH})$ gene. All the selected exons of $\mathrm{GH}$ gene were amplified through specific primer sets. The HaeIII enzyme was used for the detection of polymorphism in all the amplified PCR products (GH1, GH2, GH4, GH5, and GH6) of growth hormone gene. The HaeIII-based RFLP results showed that all the growth hormone gene regions were monomorphic in both high and low body weight goats (Figures 2).
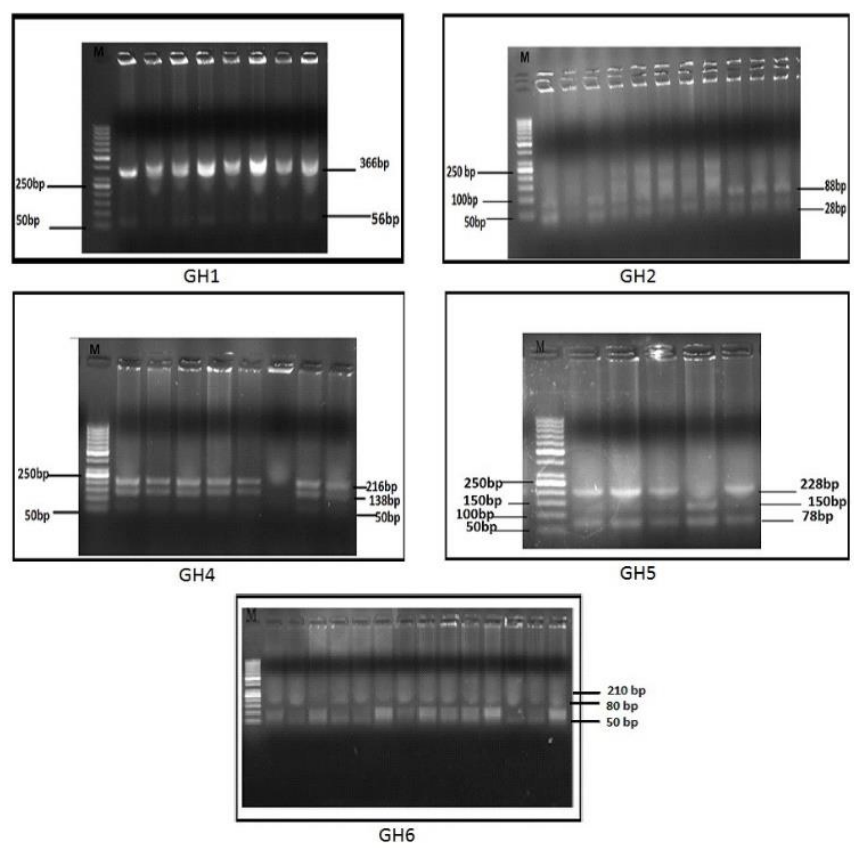

Figure 2. GH1, GH2, GH4, GH5 and GH6 are digested with HaeIII enzymes. M represent 50 bp DNA ladder. After digestion with restriction enzyme, GH1 showed two fragment of $366 \mathrm{bp}$ and $56 \mathrm{bp}$. GH2 showed $88 \mathrm{bp}$ and $28 \mathrm{bp}$. GH4 showed three fragments $216 \quad$ bp, 138 bp, 50 -bp respectively.GH5 showed three fragments 228 bp, $150 \mathrm{bp}, 78 \mathrm{bp}$ respectively while GH6 showed three fragments of size $210 \mathrm{bp}, 80 \mathrm{bp}$, and $50 \mathrm{bp}$ respectively 
Sequencing Results of Growth Hormone Gene (GH): Finally, five exons of growth hormone gene were sequenced. The sequences from low body weight animals were compared with sequences of high body weight, and one single nucleotide polymorphism was identified in GH1 (exon 2). This substitution mutation $(\mathrm{A}>\mathrm{G})$ at position 825bp was changing CGA codon to CAA resulting in an amino acid change from Threonine to Alanine (Figure4, and Figure 5).

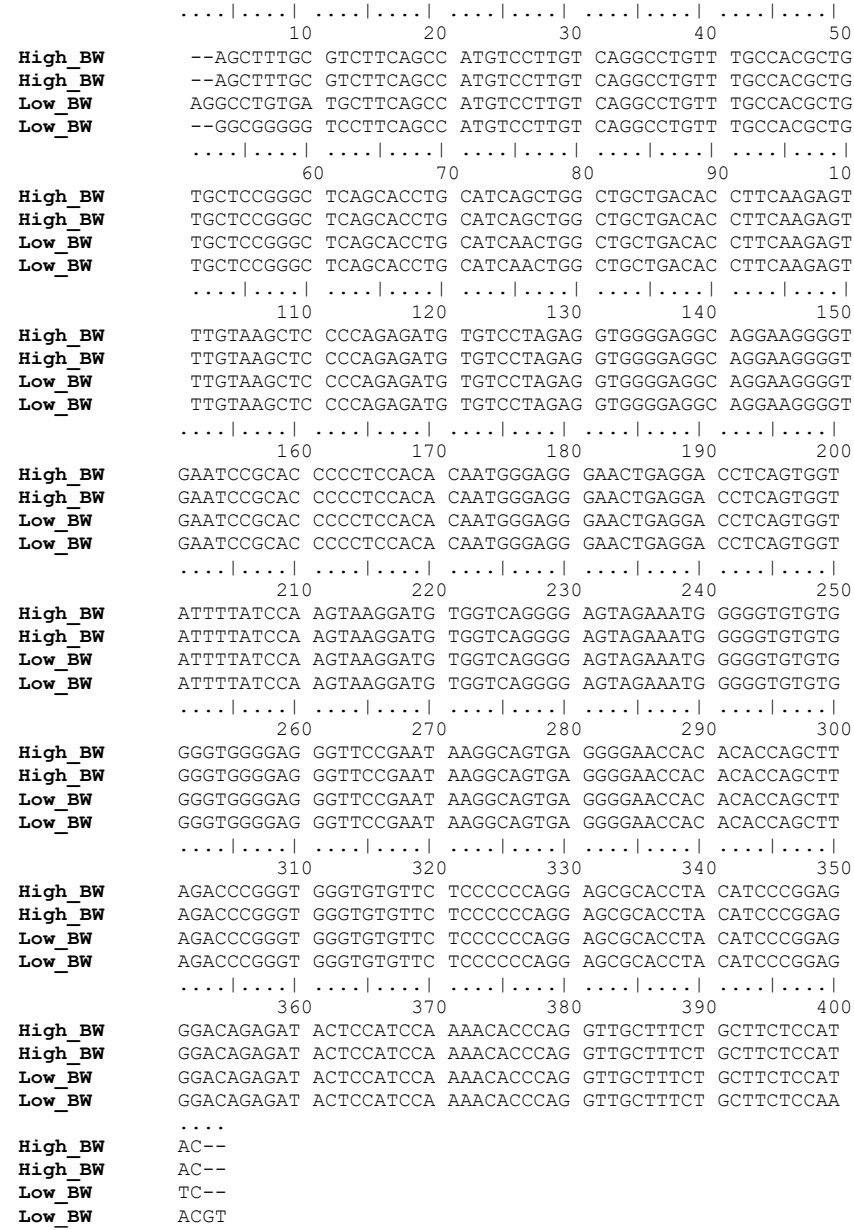

Figure 3. Sequence Alignment of GH1 of high body weight (High_BW) and low body weight (Low_BW) animals.

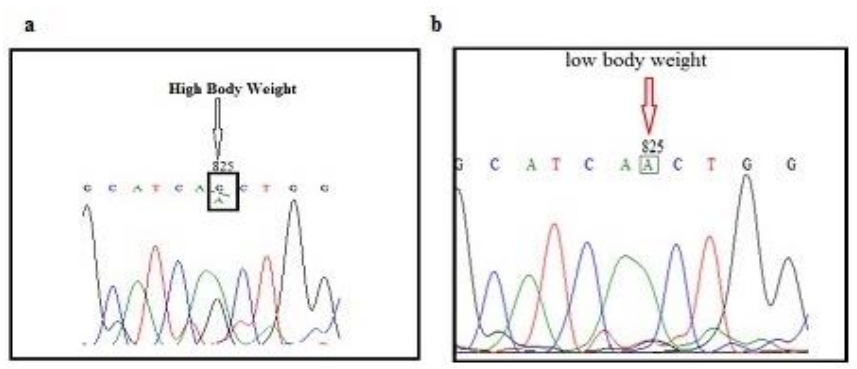

Figure 4. Mutation at position $825 \mathrm{~A}>\mathrm{G}(\mathrm{a}, \mathrm{b})$.

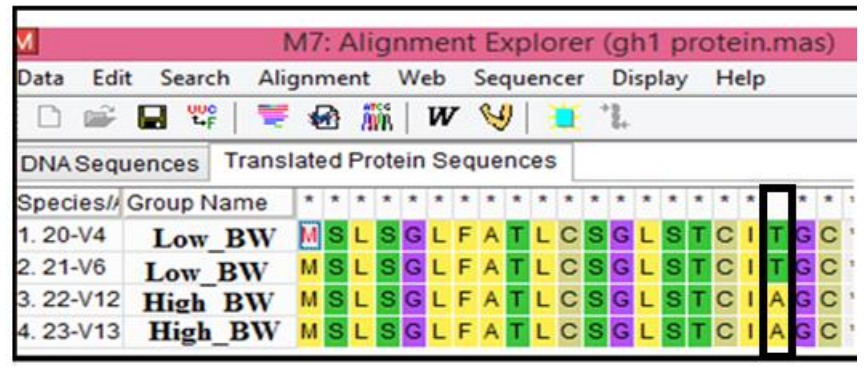

Figure 5. Pictorial view of Protein Translation. The substitution mutation (A > G) of CGA to CAA at position 825bp caused an amino acid change from Threonine to Alanine.

Sequence alignment of GH6: One insertion mutation was identified at position 1546bp in GH6 (intron 4) by comparing the sequences of low and high body weight animals (Figure 6, and Figure 7).
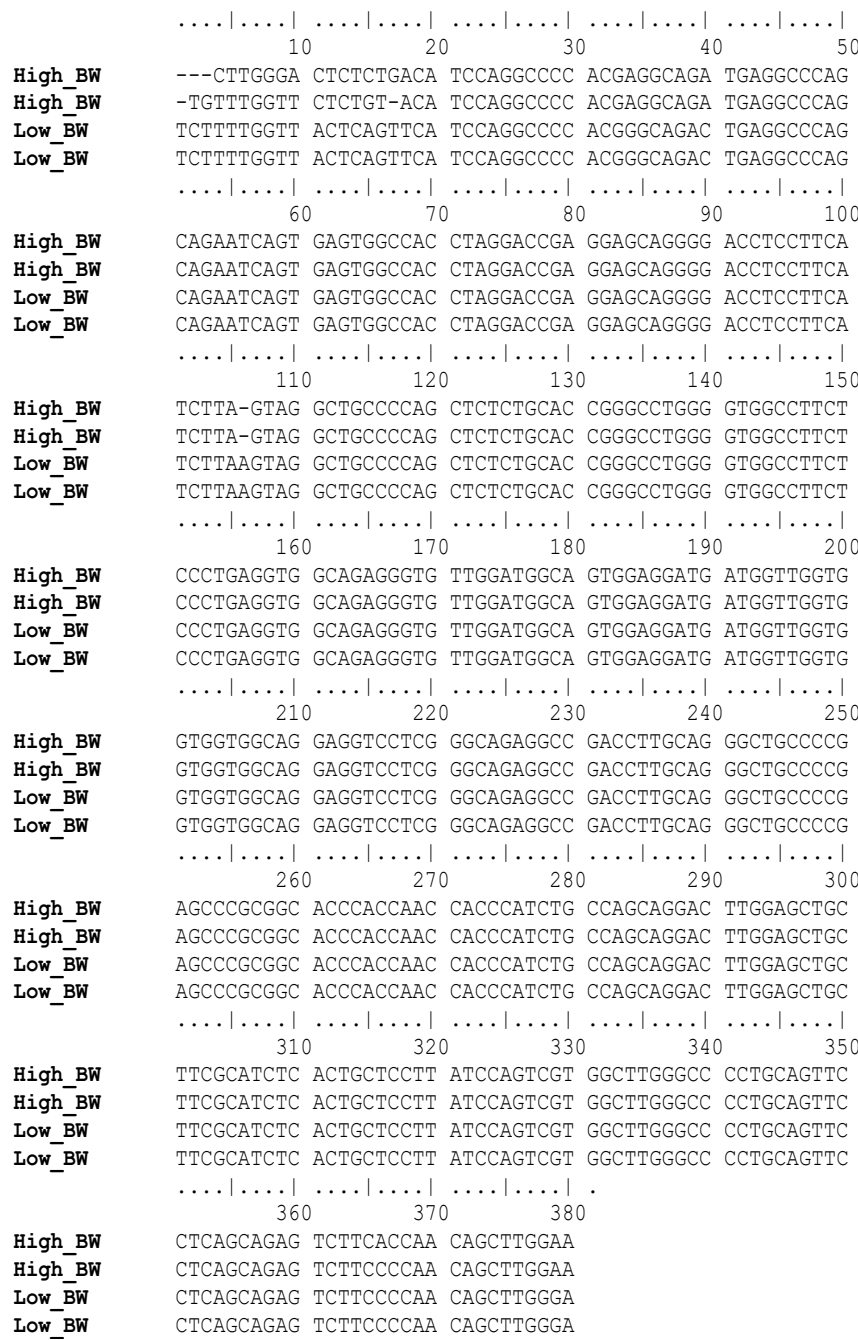
---CTTGGGA CTCTCTGACA TCCAGGCCCC ACGAGGCAGA TGAGGCCCAG -TGTTTGGTT CTCTGT-ACA TCCAGGCCCC ACGAGGCAGA TGAGGCCCAG TCTTTTGGTT ACTCAGTTCA TCCAGGCCCC ACGGGCAGAC TGAGGCCCAG TCTTTTGGTT ACTCAGTTCA TCCAGGCCCC ACGGGCAGAC TGAGGCCCAG

$\left.\left.\left.\ldots|\ldots|\right|_{60} \ldots|\ldots|{ }_{70} \ldots|\ldots|\right|_{80} \ldots|\ldots|{ }_{90} \ldots|\ldots|\right|_{100}$

CAGAATCAGT GAGTGGCCAC CTAGGACCGA GGAGCAGGGG ACCTCCTTCA CAGAATCAGT GAGTGGCCAC CTAGGACCGA GGAGCAGGGG ACCTCCTTCA CAGAATCAGT GAGTGGCCAC CTAGGACCGA GGAGCAGGGG ACCTCCTTCA CAGAATCAGT GAGTGGCCAC CTAGGACCGA GGAGCAGGGG ACCTCCTTCA $\ldots|\ldots| \ldots|\ldots| \ldots|\ldots| \ldots|\ldots| \ldots|\ldots| \ldots \mid$ $\begin{array}{lllll}110 & 120 & 130 & 140 & 150\end{array}$ TCTTA-GTAG GCTGCCCCAG CTCTCTGCAC CGGGCCTGGG GTGGCCTTCT TCTTA-GTAG GCTGCCCCAG CTCTCTGCAC CGGGCCTGGG GTGGCCTTCT TCTTAAGTAG GCTGCCCCAG CTCTCTGCAC CGGGCCTGGG GTGGCCTTCT TCTTAAGTAG GCTGCCCCAG CTCTCTGCAC CGGGCCTGGG GTGGCCTTCT

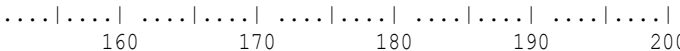
CCCTGAGGTG GCAGAGGGTG TTGGATGGCA GTGGAGGATG ATGGTTGGTG CCCTGAGGTG GCAGAGGGTG TTGGATGGCA GTGGAGGATG ATGGTTGGTG CCCTGAGGTG GCAGAGGGTG TTGGATGGCA GTGGAGGATG ATGGTTGGTG CCCTGAGGTG GCAGAGGGTG TTGGATGGCA GTGGAGGATG ATGGTTGGTG

$\left.\left.\left.\left.\cdots|\cdots|\right|_{210} \cdots|\cdots|{ }_{220} \cdots|\cdots|\right|_{230} \cdots|\cdots|\right|_{240} \cdots|\cdots|\right|_{250}$
GTGGTGGCAG GAGGTCCTCG GGCAGAGGCC GACCTTGCAG GGCTGCCCCG GTGGTGGCAG GAGGTCCTCG GGCAGAGGCC GACCTTGCAG GGCTGCCCCG GTGGTGGCAG GAGGTCCTCG GGCAGAGGCC GACCTTGCAG GGCTGCCCCG GTGGTGGCAG GAGGTCCTCG GGCAGAGGCC GACCTTGCAG GGCTGCCCCG $\ldots|\ldots| \ldots|\ldots| \ldots|\ldots| \ldots|\ldots| \ldots|\ldots| \ldots|\ldots|$

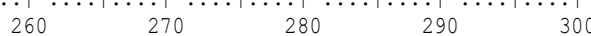
AGCCCGCGGC ACCCACCAAC CACCCATCTG CCAGCAGGAC TTGGAGCTGC AGCCCGCGGC ACCCACCAAC CACCCATCTG CCAGCAGGAC TTGGAGCTGC AGCCCGCGGC ACCCACCAAC CACCCATCTG CCAGCAGGAC TTGGAGCTGC AGCCCGCGGC ACCCACCAAC CACCCATCTG CCAGCAGGAC TTGGAGCTGC $\ldots|\ldots| \ldots|\ldots| \ldots|\ldots| \ldots|\ldots| \ldots|\ldots| \ldots|\ldots| \ldots \mid$ TTCGCATCTC ACTGCTCCTT ATCCAGTCGT GGCTTGGGCC CCTGCAGTTC TTCGCATCTC ACTGCTCCTT ATCCAGTCGT GGCTTGGGCC CCTGCAGTTC TTCGCATCTC ACTGCTCCTT ATCCAGTCGT GGCTTGGGCC CCTGCAGTTC TTCGCATCTC ACTGCTCCTT ATCCAGTCGT GGCTTGGGCC CCTGCAGTTC

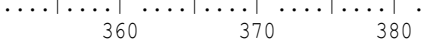

CTCAGCAGAG TCTTCACCAA CAGCTTGGAA

CTCAGCAGAG TCTTCCCCAA CAGCTTGGAA

CTCAGCAGA TCTTCCCCAA CAGCTTGGGA
CTCAGCAGAG TCTTCCCCAA CAGCTTGGGA

Figure 6. Sequence alignment of GH6 gene region 
Pictorial view of Mutation and its position.
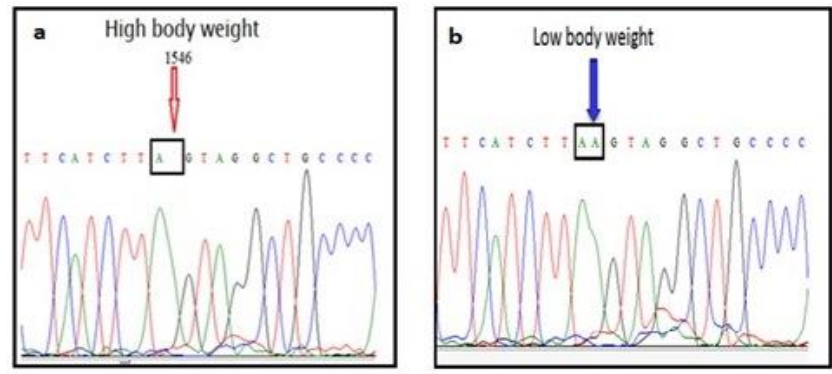

Figure 7. Deletion Mutation at 1546 position (a, b)

Insulin-like growth factor-1 (IGF-1) gene

The amplified product of exon 4 and partial intron 4 of IGF1 gene was $363 \mathrm{bp}$ long. The IGF-1 gene fragments were amplified by PCR and run on $1.2 \%(\mathrm{~W} / \mathrm{V})$ agarose gel electrophoresis as shown in Figure 8.

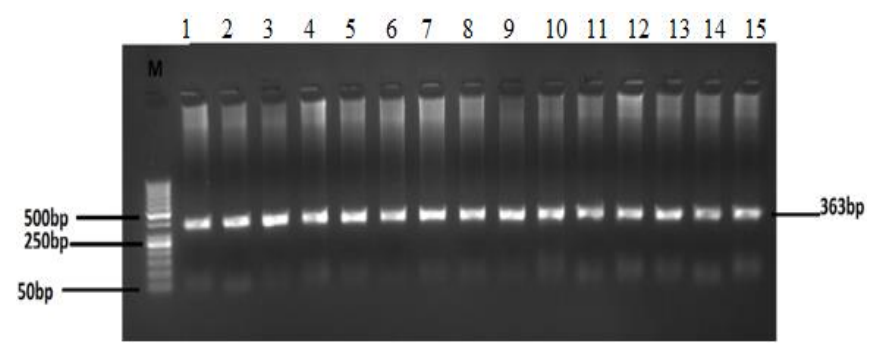

Figure 8. IGF-1 fragments amplified by PCR

PCR-Restriction Fragment Length Analysis of Insulin-like growth factor -1 (IGF-1) gene: The genotyping of IGF-1 gene was done after digesting the PCR product (363bp) by the restriction enzyme HaeIII and the digested fragments were run on agarose gel electrophoresis. The fragments obtained were of different sizes and categorized into different genotypes as follows, 363bp for AA genotype, 273bp and $90 \mathrm{bp}$ for BB genotype and, $363 \mathrm{bp}, 273 \mathrm{bp}$, and $90 \mathrm{bp}$ for $\mathrm{AB}$ genotype after digestion with HaeIII, as shown in Figure 9.

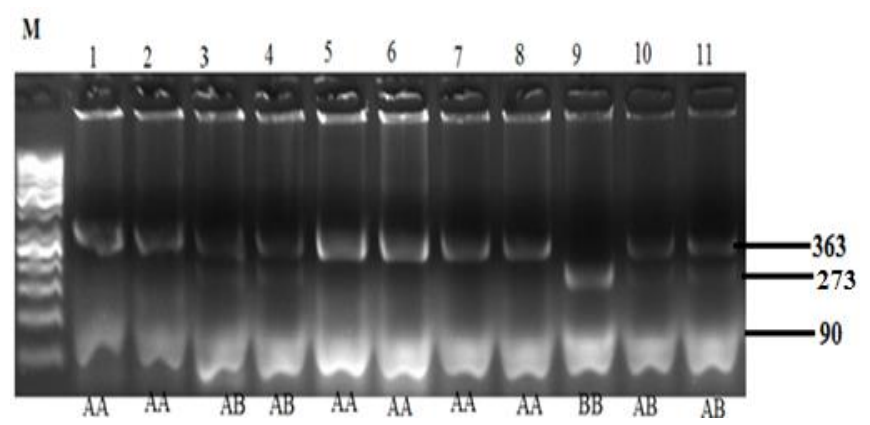

Figure 9. RFLP Pattern of IGF-1 PCP Product

Statistical Analysis of Insulin-like Growth Factor-1 gene: The observed genotypes were (AA, $\mathrm{AB}$, and $\mathrm{BB}$ ) and genotypic frequencies of $\mathrm{AA}, \mathrm{AB}$, and $\mathrm{BB}$ were $0.39,0.47$, and 0.086 respectively (Table 2 ). The frequency for allele $A$ and $\mathrm{B}$ was 0.65 and 0.35 respectively (Table 2). The association analysis between different IGF-1 genotypes and growth traits including adult body weight, and body measurements (body length, body height, and chest girth), taken at adult age, was performed. The results of association analysis of different genotypes with body weight and body measurements are shown in Table 3. Genotype AA was found significantly $(\mathrm{P}<0.05)$ associated with low body weight $(38.18+0.37 \mathrm{~kg})$ while $\mathrm{BB}$ genotype was associated $(\mathrm{P}<0.05)$ with high body weight $47.13+0.78 \mathrm{~kg}$. Moreover, genotype $\mathrm{AB}$ showed additive effect and significant association with body weight of up to $40.45+0.31 \mathrm{~kg}$. Similarly maximum wither height and body length was found in $\mathrm{BB}(32.25+0.33$, $31.93+0.27$ inches $)$ genotype following $\mathrm{AB}(31.93+0.27$, $31.16+0.35)$ and $\mathrm{AA}(31.62+0.68,30.87+0.86)$ genotype. Likewise, maximum heart girth was observed in $\mathrm{BB}(33.65+$ $0.11)$ genotype followed by $\mathrm{AB}(31.52+0.90)$ and $\mathrm{AA}(33.25$ $+0.24)$ genotype.

\section{DISCUSSION}

In livestock production, animal growth traits are always of foremost concern for breeders due to their economic value

Table 2. Observed genotype, Allelic frequency and Genotype frequency of IGF-1 gene in Beetal goats

\begin{tabular}{lcccccccc}
\hline Breed & \multicolumn{3}{c}{ Observed genotype } & \multicolumn{3}{c}{ Allelic Frequency } & \multicolumn{3}{c}{ Genotype Frequency } \\
\hline Beetal goat & $\mathrm{AA}$ & $\mathrm{AB}$ & $\mathrm{BB}$ & $\mathrm{A}$ & $\mathrm{B}$ & $\mathrm{AA}$ & $\mathrm{AB}$ & $\mathrm{BB}$ \\
& 23 & 30 & 7 & 0.65 & 0.35 & 0.39 & 0.47 & 0.09 \\
\hline
\end{tabular}

Table 3. Association of IGF-1 genotypes with Body weight, Wither height, Body length and Heart girth in Beetal goats

\begin{tabular}{|c|c|c|c|c|}
\hline Genotype & $\begin{array}{l}\text { Body weight } \\
---(k g)---\end{array}$ & Withers height & $\begin{array}{l}\text { Body length } \\
-- \text { (inch)--... }\end{array}$ & Heart girth \\
\hline$\overline{\mathrm{AA}}$ & $38.18 \pm 0.37^{\mathrm{b}}$ & $31.62 \pm 0.68$ & $30.87 \pm 0.86$ & $33.25 \pm 0.24$ \\
\hline $\mathrm{AB}$ & $40.45 \pm 0.31^{\mathrm{b}}$ & $31.93 \pm 0.27$ & $31.16 \pm 0.35$ & $31.52 \pm 0.90$ \\
\hline BB & $47.13 \pm 0.78^{\mathrm{a}}$ & $32.25 \pm 0.33$ & $31.97 \pm 0.42$ & $33.65 \pm 0.11$ \\
\hline
\end{tabular}

Means with different superscripts within the same column are significant at $\mathrm{P}<0.05$ 
(Zhang et al., 2008a; Zhang et al., 2008b). In the current study, we used the GH and IGF-1 as candidate genes to find out the polymorphism and its association with the growth traits in Beetal goats.

Growth hormone gene $(\boldsymbol{G H})$ : In the current study, five exons of $\mathrm{GH}$ were amplified to detect the PCR-RFLP based mutation by digesting with HaeIII restriction enzyme. However, all tested animals of low and high body weight were found monomorphic (Table 1) in the present study. Although the same RFLP pattern was also observed by Hua et al. (2009) who reported the polymorphic nature of mutation in first four exons of growth hormone gene in Boer goat. In contrast to our results, An et al. (2010) reported polymorphism in exon 1, 3, 4 , and 5 of growth hormone gene in four different populations of goats in China. Moreover, sequence data of exonic regions of growth hormone gene revealed two point mutations in this study. One SNP was observed in exon 2 and this was a substitution mutation $(\mathrm{A}>\mathrm{G})$ changing $\mathrm{CGA}$ to $\mathrm{CAA}$ at position $825 \mathrm{bp}$. This was non-synonymous mutation causing an amino acid change from Threonine to Alanine. Additionally, one deletion was identified at position $1546 \mathrm{bp}$ in intron 4 region of growth hormone gene. From our results, it is likely that the said mutation at $825 \mathrm{bp}$ position which causes change in the amino acid from hydrophobic to hydrophilic group may be one of reason of variation in the body weight in Beetal goat. Additionally, another insertion mutation was found in the intron 4 region of $\mathrm{GH}$ gene. There is possibility that these observed mutations might be responsible for variation in body weight by changing the biological function in Beetal goat. It also seems likely because growth hormone plays an important role in the growth of different livestock species as well as in other biological processes such as metabolism and lactation (Jiang and Lucy, 2001; Ge et al., 2003; Supakorn et al., 2007; An et al., 2011) and reproduction (Scaramuzzi et al., 1999). In consistent with our resutls, Hua et al. (2009) found two mutations, one in the exon 2 at position $781 \mathrm{bp}$ and another at position $1575 \mathrm{bp}$. Although the mutation found by them in exon 2 was very close to the mutaion observed in our tested animal of Beetal goats. It is likely that breed difference might be one of the reason for the difference of nucleotide polymorphism between these two studies.

Insulin-like growth factor-1 gene (IGF-1): In our study, three genotypes (363 for AA genotype, 264 and 90 for BB genotype and, 363, 264 and 90 for $\mathrm{AB}$ ) were observed in exon 4 and intron 4 of IGF-1 gene by using PCR-RFLP method. The results showed the polymorphic nature of mutation in Beetal goat. These results are in accordance with the findings of Wu-Jun et al., (2010) and Negahdary et al., (2013) who also found three genotypes for IGF-1 in their goat population.

In the current study, we also assessed the association between different IGF-1 genotypes and growth traits including the body weight, body length, body height, chest girth and body weight. Our results showed that genotype AA was associated with low body weight $(38.18 \mathrm{Kg})$ and while $\mathrm{BB}$ genotype was significantly associated $(\mathrm{P}<0.05)$ with higher body weight $47.13 \mathrm{Kg}$. However, genotype AB was significantly associated with $40.45 \mathrm{~kg}$ body weight showing the additive effects of allele B. In consistent with our results, Zhang et al. (2008c) observed mutation in intron 4 of IGF-1 gene and found significant association with birth weight, and body weight at 6 and 12 months in Nanjiang Huang goats. Similar results were found in the in Markhoz goat breed of Iran by Rasouli et al. (2017) who estimated a significant effect of different genotypes of IGF-1 and IGFBP-3 gene with the weaning weight, and average daily weight gain. In our study, the frequency of mutant allele (B) was low (0.35) as compared to 0.65 frequency of wild allele $(\mathrm{A})$, therefore, the $\mathrm{BB}$ genotype was observed in a small proportion of samples. Likewise, same mutation was observed in Guanzhong and Xinong-Saanen breeds by (Deng et al., 2010). Additionally, the frequency of mutant allele was low in both of goat breeds but in contrast to our findings, this polymorphism was not associated with any of growth traits. Similarly, contrasting results were also found by Zhang et al. (2008) who revealed no single nucleotide polymorphism (SNP) in the $5^{\prime}$ flanking region of the IGF-I gene. However, the reason for the low frequency of $\mathrm{BB}$ genotype in our population might be the limited number of tested animal in current study. The association studies related to IGF-I gene polymorphism and growth traits showed different pattern of results in different breeds. Significant association of the polymorphism in IGF-1 gene was observed with daily gain in Baluchi sheep (Tahmoorespur et al., 2009). Likewise, same polymorphism was associated with growth traits in sheep and in Kurdish goat (Kazemi et al., 2011; Kurdistani et al., 2013). In contrast to our results, Wang et al., (2011) studied the same polymorphism in three breeds of goats and found no significant association with birth weight. These inconsistent results might be due to linkage disequilibrium of the IGF-I gene with QTLs of these observed traits. However to validate the effect of IGF-1 gene with growth traits in Beetal goat, more studies are required with larger number of animals.

Conclusion: On the basis of our data it is concluded that mutations already reported in the exonic regions of Growth hormone gene were monomorphic in Beetal goat. Moreover, one substitution mutation in exon $2 \mathrm{G}>\mathrm{A}$ at position $825 \mathrm{bp}$ along with one insertion mutation in intron 4 at position $1546 \mathrm{bp}$ was also observed in the tested animals of Beetal goat. The IGF-1 gene was proven of prime importance because IGF-1 gene was polymorphic and had significant association with body weight and body measurements. It is suggested that identified variants can be used as genetic markers in order to select the Beetal goat for the growth-related traits in future. 
Acknowledgement: We are thankful to Mr. Imran Mohsin and Mr. Talib Hussain for the collection of phenotypic data and assistance in blood sampling. Also thankful to Mr. Mustansar Hussain for helping in DNA extraction.

\section{COMPLIANCE WITH ETHICAL STANDARDS}

Conflict of interest: The authors declare that they have no conflict of interest.

\section{REFERENCES}

An, X., L. Wang, J. Hou, G. Li, Y. Song, J. Wang and B. Cao. 2011. Novel polymorphisms of goat growth hormone and growth hormone receptor genes and their effects on growth traits. Mol. Bio. Rep. 38:4037-4043.

An, X., L. Wang, J. Hou, G. Li, Y. Song, J. Wang, M. Yang, Y. Cui and B. Cao. 2010. Novel polymorphisms of goat growth hormone and growth hormone receptor genes and their effects on growth traits. Molecular Biology Reports. 38:4037-4043.

Bai, H., P. Kang, A.M. Hernandez and M. Tatar. 2013. Activin Signaling Targeted by Insulin/dFOXO Regulates Aging and Muscle Proteostasis in Drosophila. PLoS Gen.. 9:1003941e.

De la Rosa Reyna, X.F., H.M. Montoya, V.V. Castrelln, A.M.S. Rincn, M.P. Bracamonte and W.A. Vera. 2010. Polymorphisms in the IGF1 gene and their effect on growth traits in Mexican beef cattle. Genet. Mol. Res. 9:875-883.

Deng, C., R. Ma, X. Yue, X. Lan, H. Chen and C. Lei. 2010. Association of IGF-1 gene polymorphism with milk yield and body size in Chinese dairy goats. Genet. Mol. Biol. 33:266-270.

Dettori, M.L., M. Pazzola, E. Pira, P. Paschino and G.M. Vacca. 2015. The sheep growth hormone gene polymorphism and its effects on milk traits. J. Dairy Res. 82:169-176.

Gupta, N., A. Pandey, G. Malik and S.C. Gupta. 2009. Single nucleotide polymorphism ( SNP ) in growth hormone gene of Jakhrana , a prominent milk goat breed in India. Small Rumin. Res. 81:35-41.

Hua, G.H., S.L. Chen, J.N. Yu, K.L. Cai, C.J. Wu, Q.L. Li, C.Y. Zhang, A.X. Liang, L. Han, L.Y. Geng, Z. Shen, D.Q. Xu and L.G. Yang. 2009. Polymorphism of the growth hormone gene and its association with growth traits in Boer goat bucks. Meat Sci. 81:391-395.

Ishida, T., A. Umebayashi, S. Tsuruta, R. Akashi and H. Harada. 2010. Polymorphisms in growth hormone gene and their associations with calf weight in Japanese Black cattle. Animal Sci. J. 81:623-629.

Jiang, H. and M.C. Lucy. 2001. Variants of the 5'-untranslated region of the bovine growth hormone receptor mRNA: isolation, expression and effects on translational efficiency. Gene. 265:45-53.
Kazemi, S.M., H. Emrani and S. Gharahveysi. 2011. Study and Identification of Insulin-Like Growth Factor-I Gene Polymorphisms in Zel Sheep Population. Americ. J. Anim. Vet. Sci. 6:176-179.

Khan, M. and F. Ashfaq .2012. 'Dairy Goats in Pakistan: Potential, Opportunities and Challenges, Proce of the 1st Asia Dairy Goat Conf.' Kuala Lumpur, Malaysia.

Khan, M., M. Khan and S. Mahmood. 2008. Genetic resources and diversity in Pakistani goats. Int J Agri Biol. 10:227-231.

Kurdistani, Z.K., J. Rostamzadeh, A. Rashidi and M.E. Davis. 2013. Evaluation of insulin-like growth factor-I gene polymorphism on growth traits and yearling fleece weight in goats. Small Rumin. Res. 111:10-15.

Lan, X.Y., H. Chen, C.Y. Pan, L.J. Ming, C.Z. Lei, L.S. Hua, C.L. Zhang and S.R. Hu. 2007. Polymorphism in Growth Hormone Gene and its Association with Production Traits in Goats. J. App. Ani. Res. 32:55-60.

Liu, W.J., G.X. Fang, Y. Fang, K.C. Tian, X.X. Huang, X.K. Yao, M.Y.H. Wang, Y.Z. Huang, J.J. Xin, Y.P. Xin, S.G. $\mathrm{Yu}$ and H. Chen. 2010. The polymorphism of a mutation of IGF1 gene on two goat breed of China. J. Anim. Vet. Adv. 9:790-794.

Malveiro, E., M. Pereira, P.X. Marques, I.C. Santos, C. Belo, R. Renaville and A. Cravador. 2001. Polymorphisms at the five exons of the growth hormone gene in the algarvia goat: possible association with milk traits. Small Rumin. Res. 41:163-170.

Negahdary, M., A. Hajihosseinlo and M. Ajdary. 2013. PCRSSCP variation of IGF1 and PIT1 genes and their association with estimated breeding values of growth traits in Makooei sheep. Gen. Res. Int.1:1-6.

Othman, O.E., M.F. Abdel-Samad and N.A.A. El-Maaty. 2016. Evaluation of insulin-like growth factor-I gene polymorphism in Egyptian small ruminant breeds. Afric J of Biotech. 15:2714-2719.

Payne, R.W., D.A. Murray, S.A. Harding, D.B. Baird and D.M. Soutar. 2011. An Introduction to GenStat for Windows (14 ${ }^{\text {th }}$ Ed.). VSN International, Hemel Hempstead, UK.

Rasouli, S., A. Abdolmohammadi, A. Zebarjadi and A. Mostafaei. 2017. Evaluation of Polymorphism in IGF-I and IGFB-3 Genes and their Relationship tith Twinning Rate and Growth Traits in Markhoz Goats. Ann. Ani. Sci. $17: 1-23$.

Sambrook, J. and R.W. Russell. 2001. Molecular cloning: A laboratory manual. 3rd ed. Cold Spring Harbor Laboratory Press, New York.pp. 2344.

Scaramuzzi, R.J., J.F. Murray, J.A. Downing and B.K. Campbell. 1999. The effects of exogenous growth hormone on follicular steroid secretion and ovulation rate in sheep. Domes. Ani. Endo. 17:269-277.

Sharma, A., G. Dutt, S. Jayakumar, V. Saroha and S.P. Dixit. 2014. Sequence characterization and genetic variability 
analysis of GHR, IGF1, and IGFBP-3 genes in nine Indian goat breeds. J. Appl. Anim. Res. 42:361-365.

Silveira, L.G.G., L.R. Furlan, R.A. Curi, A.L.J. Ferraz, M.M.d. Alencar, L.C.A. Regitano, C.L. Martins, M.d.B. Arrigoni, L. Suguisawa, A.C. Silveira and H.N.d. Oliveira. 2008. Growth hormone 1 gene (GH1) polymorphisms as possible markers of the production potential of beef cattle using the Brazilian Canchim breed as a model. Genet. Mol. Bio. 31:874-879.

Singh, P.P., S.S. Tomar, M.S. Thakur and A. Kumar. 2015. Polymorphism and association of growth hormone gene with growth traits in Sirohi and Barbari breeds of goat. Vet World 8:382-387.

Sudhir, K., S. Glen and T. Koichiro. 2016. MEGA7: Molecular Evolutionary Genetics Analysis Version 7.0 for Bigger Datasets. Mol. Biol. Evol. 33:1870-1874.

Supakorn, C., S. Mekchay, V. Siripholvat, P. Sopannarath, S. Koonawootrittriron and S. Tumwasorn. 2007. Effect of genetic polymorphism of bovine growth hormone gene on preweaning growth traits in a Thai multibreed beef population. Kaset. J. Natu. Sci. 41:484-492.

Tahmoorespur, M., M.V. Valeh, M.R. Nassiry, A.H. Moussavi and M. Ansary. 2009. Association of the polymorphism in the 50 flanking region of the ovine IGFI gene with growth traits in the Baluchi sheep. S. Afr. J. Anim. Sc. 39:97-101.

Thompson, J.D., G. G Higgins and T.J. Gibson. 1994. CLUSTAL W: improving the sensitivity of progressive multiple sequence alignment through sequence weighting, position-specific gap penalties and weight matrix choice. Nucleic Acid Research.22:4673-4680.

Trukhachev, V., V. Belyaev, A. Kvochko, A. Kulichenko, D. Kovalev, S. Pisarenko, A. Volynkina, M. Selionova, M.
Aybazov, S. Shumaenko, A. Omarov, T. Mamontova, N. Golovanova, O. Yatsyk and A. Krivoruchko. 2016. Genes expression profiles in the loin muscle of manych merino sheep with different live weight. Bulgar J Vet Med.19:19-29.

Wang, Y., L. Yuanxiao, Z. Nana, W. zhanbin and B. Junyan. 2011. Polymorphism of Exon 2 of BMP15 Gene and Its Relationship with Litter Size of Two Chinese Goats. Asian-Aust. J. Anim. Sci. 24:905-911.

Wickramaratne, S., B. Ulmek, S. Dixit, S. Kumar and M. Vyas. 2011. Use of growth hormone gene polymorphism in selecting osmanabadi and sangamneri goats. Trop. Agri. Res. 21:398-411.

Wu-Jun, L., F. Guang-Xin, F. Yi, T. Ke-Chuan, H. Xi-Xia, Y. Xin-Kui, W. Mou, Y. Hui, H. Yong-Zhen, X. Jing-Jing, X. Ya-Ping, Y. Shi-Gang and C. Hong. 2010. The Polymorphism of a Mutation of IGF-1 Gene on Two Goat Breeds in China. J. Ani. Vet. Adv. 9:790-794.

Zhang, C.-L., Y.-H. Wang, H. Chen, X.-Y. Lan, C.-Z. Lei and X.-T. Fang. 2008a. Association between variants in the 5 -untranslated region of the bovine MC4R gene and two growth traits in Nanyang cattle. Mol. Bio. Rep. 36:18391843.

Zhang, C., L. Yang and Z. Shen. 2008b. Variance components and genetic parameters for weight and size at birth in the Boer goat. Liv. Sci. 115:73-79.

Zhang, C., W. Zhang, H. Luo, W. Yue, M. Gao and Z. Jia. 2008c. A New Single Nucleotide Polymorphism in the IGF-I Gene and Its Association with Growth Traits in the Nanjiang Huang Goat. Asian-Aust. J. Anim. Sci. 21:1073-1079. 